Journal of Social Sciences 8 (2): 182-188, 2012

ISSN 1549-3652

(C) 2012 Science Publications

\title{
Theater Activities for Jung Opera Audience: An Educational Urgency
}

\author{
Elita Maule \\ Department of Education, Conservatory of Music of Bozen, Italy
}

\begin{abstract}
Problem statement: Numerous studies have led researchers to conclude that the sociodemographic profile of the public of classical music appears to be quite generalizable. However, the survey of the opera public, a classical music subgenre that is often associated with theater performances, appears to be much more difficult to quantify and has not yet been the subject of specific investigations (1). The drastic decrease in audience attendance, especially among young people, has led to a radical change in the management of all the opera houses in Europe (2). The research here presented has explored, through a representative sample of twenty-four Theatres in twelve different European countries, all practitioners of Opera Education, the complex interaction of personal, social and cultural factors that have led the theatres to interact with the educational system and the school curricula (3). A research on the different methods applied for teaching Opera to young people has led to attention being given especially to what is now called "Dramatic Interpretation of Music Theatre", a method developed within Germany but now accepted by the majority of Opera Houses in Northern Europe (4). Approach: The research on educational projects for young people was made through the analysis of the web-sites of 24 theatres: 12 of these were members of Reseo, the network of partners involved in opera education that was proposed and promoted by the European Community in 1999; 12 other theatres, although belonging to other such networks were not members of Reseo. Results: (1) Opera seems to attract a rather limited public that occupies, in terms of number, the last places in the classification; the amount of people who listen to classical music is double that of those who listen to opera. (2). Educating the audience and, therefore, organizing also didactic projects for young people, has become for theaters a means to ensure their future survival. (3). The European Opera theaters adopt common strategies to attract and increase the young audience. (4) The European Opera theaters adopt a common pedagogical approach. Conclusion: To cope with increasing costs and decreasing youth audience, the Opera theaters of Europe have adopted common organizational and pedagogical strategies focusing their activities on educational projects for schools.
\end{abstract}

Key words: Opera theaters, the public of opera, educating the audience, University of Fribourg $(\mathrm{CH})$

\section{INTRODUCTION}

Opera represents a cultural heritage of great significance. It has even played an important role in the construction of the European identity, not only due to the artistic-musical aspects involved, but also because numerous generations of men and women of different languages and of varying provenance and social background, have been caught up in its affective and emotional world (Bianconi, 2005). Opera is considered a historical patrimony in which many countries recognize themselves and that governments unanimously believe should be safeguarded and protected (Council Conclusions, 1997).

Opera, however, is today a form of art whose survival is threatened by an increasingly diminished audience; the average age of opera-goers is steadily increasing (Colbert, 2000); the generational exchange indispensable to guarantee its future is lacking. The fall in the number of opera-goers that started the 1980s and is worsening over time led to a veritable revolution within opera organisations. Since then the watchword of European opera-houses has become Educate young people to opera (Nattiez et al., 2002). This objective has been pursued by the setting up of Educational departments, now present in all civic theatres throughout Europe. Still largely or totally unknown in the field of research, these Departments have been protagonists in a change that has involved not only theatres, schools and families, but also many other communities such as juvenile prisons, rehabilitation centres, centres for the disabled and religious centres dedicated to the integration of the young (Brinkmann et al., 2010).

The decision to embark on an educational approach was undoubtedly favoured by a new tendency that was becoming increasingly more consistent within the Science of Education. Already in the 1970s the idea of

Corresponding Author: Elita Maule, Department of Education, Conservatory of Music of Bozen, Italy 


\section{J. Social Sci., 8 (2): 182-188, 2012}

an open education system endorsed forms of collaboration between school and territory aimed at introducing the innovative elements that the environmental culture had always produced and disseminated but which the education sector, with its jumbled legal system, had never been able to embrace in acceptable times (Frabboni and Guerra, 1991). The 1980s, then, saw the start of a consolidated move towards the implementation of an integrated educational system, designed for the purposes of coming to terms with the very rapid intrusion of a large number of new figures, both public and private, within the education sector (Elita, 2011). The move represented an attempt to readjust the balance of the whole system by fostering new possible links between the scholastic and extra-scholastic dimensions of education. The school therefore delegated part of its programme to external collaborators and the theatres arrived just at the right moment, becoming an ideal partner of the scholastic institutions and offering an environment where the young audience could be more readily reached and in large numbers.

This novel turn appears to have brought about a historical change in the dynamics that governed the organization of the theatres: singers, scenographers, dancers, costume designers, orchestral players, have since then divided their role between that of the artist and that of educator.

This new direction undertaken by theatres and opera-houses was by no means without fruit, on the contrary, the following obtained among the young audience is a sure mark of the success of the initiatives. Suffice it to consider that in 2007 alone, the Educational department of the Gran Teatre del Liceu di Barcellona counted as many as 183,600 students attending the 302 educational events arranged especially for children and schools; the Teatro Regio in Turin each year involves more than 50,000 young people while the Teatro d'opera in Rome attracts over 30,000. These figures also show how the theatres today represent an opportunity of work for many young educators in the music sector. While a fair number of collaborators are employed permanently in the organization of educational events (over 20 even in modest institutions such as the Scottish Opera), other young experts are taken on with temporary contracts. And in the 2007-8 season alone as many as 418 young external collaborators were involved in the education programmes of the Gran Teatre Del Liceu in Barcelona.
The cost of opera and its audience is the opera audience really an ugency in europe and to what extend? Already in the 1960s (Baumol and Bowen, 1981) highlighted the permanent financial difficulties (the "Cost Disease") afflicting theatres of opera and ballet. The reasons, of a structural nature, stemmed from the substantial differences between the cultural productions, defined as a "stagnant division" and that of other sectors of the economy, characterized by a constant increase in productivity (Frey, 2003). Opera is one of the most expensive forms of art; $58 \%$ of its budget covers the labour costs alone. The cost disease mentioned by (Baumol and Bowen, 1981) however, affects the opera-houses during the phase of preparation but not during that of distribution, a sector able to guarantee a certain degree of productivity (Kiefer, 2005).

To tackle these problems, theatres have for some time now moved towards a business-like type of organization and the educational interventions directed at the younger audience should be viewed precisely in terms of a marketing strategy whose main aim is to broaden the audience, especially in the direction of the younger sector, which has been shown to be in a genuine state of emergency, as underlined by numerous studies (Bentoglio, 2007; Nattiez et al., 2002). However, as Trosby argues, the taste for "good music" is an acquired taste that will increase over time with exposure. "In the household production model, the relative consumption of the arts will rise over time, non because of a shift in tastes, but because the shadow price of the arts falls as experience, understanding and other human capital attributes associated with the arts are acquired [...]. As we have noted, cultural consumpion can be interpreted as a process leading both to present satisfation and to the accumulation of knoledge and experience affecting future consumpion" (Throsby, 1994).

But is the opera audience really an ugency in Europe and to what extend?

In 2007, the Education and Culture DirectorateGeneral of the European Commission has been keen to measure public opinion on culture and values within Europe, in order to ascertain both their position and behaviour in this area. The survey was carried out by TNS Opinion and Social, interviewing 26755 citizens in the 27 Member States.

Respondents were asked how many times, if at all, they had taken part in various cultural activities over the 12 months running up to their interview (Farinha, 2007).

It is clear, as shown in Fig. 1, that "of the activities presented to respondents in this exercise, seeing a ballet, dance performance or opera is the least common activity, with less than 2 in $10(18 \%)$ doing this at least 
once and just $2 \%$ five times or more [...]. As we would perhaps logically predict, there is a clearly discernable relationship between overall participation rates and frequency of participation for the above activities. Thus, for example, over half of the vast majority of all respondents who have watched/listened to a cultural program on the television or radio, do over five times a year. Meanwhile, of the minority who attend ballet/dance/opera only a slim proportion does so over five times a year. Though the situation no doubt varies from one activity to the next, we may reasonably hypothesise that the same factors that lead to lower participation rates for certain activities also contribute to the lower frequency of participation amongst those who have an interest in that area" (Farinha, 2007):

- Such data consider the participation to ballet, dance performance or opera together

- If we consider the participation to opera itself, the results appear even smaller

A survey carried out in 2003 by the European Commission (Eurobarometer, 2003) set out to investigate the cultural requisites of the 14 States who were then candidates for entering the European Union. The percentage of spectators who, of those that had attended at least one live performance in 2003, had chosen an opera (or operetta) was found to be quite low and much lower than the percentage interested in classical music in general (The 13 candidate countries applying for European Union membership in 1999 were: Bulgaria, Cyprus, the Czech Republic, Estonia, Hungary, Latvia, Lithuania, Malta, Poland, Romania, Slovakia, Slovenia and Turkey).

As the Fig. 2 below highlights, "there is a significant difference among musical preferences in the different segments of society. The intuitive clash between age groups (the older the people are the more likely they enjoy classical music and vice versa, the younger they are, the more they like contemporary music like rock and pop) seems to be accompanied with another one that has to do with the education level of the respondents. The more educated people are, the more likely they are to attend classical music events and the less likely they are to attend folk and traditional concerts, which are the most popular among the least educated people (43\%) in every societal segment we investigate" (Eurobarometer, 2003).

Other results, providing a useful indication of preferences, are offered by European studies on the fruition of music through channels other than live performance (Eurobarometer, 2003).

Once again, as shown below in Table 1, opera seems to attract a rather limited public that occupies, in terms of number, the last places in the classification.

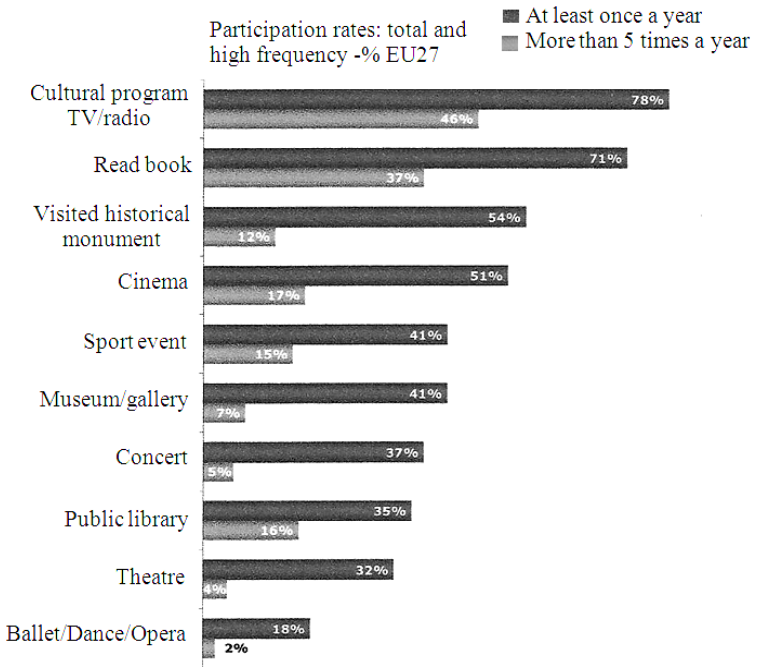

Fig. 1: Involvement of European Population in General Cultural Activities. Year 2007 (Source: European Commission, Euro barometer 2007)

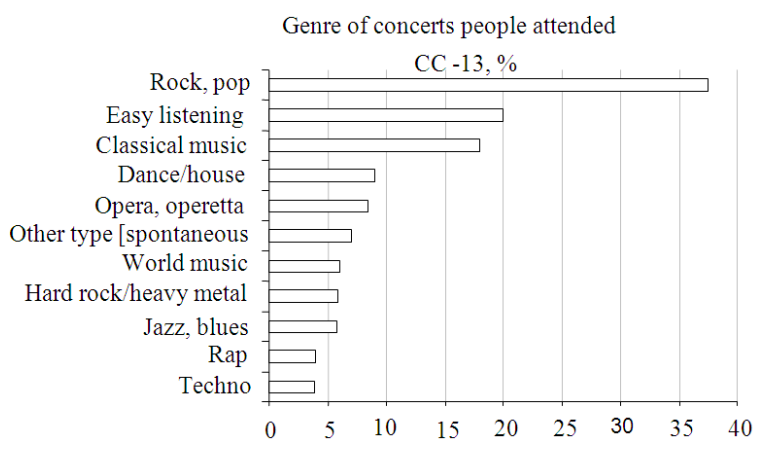

Fig. 2: Percentage of spectators in the 14 States who were then candidates for entering the European Union who had attended at least one live performance in 2003 (Source: European Commission, Euro barometer 2003)

It is interesting to observe how the amount of people who listen to classical music is double that of those who listen to opera.

The statistics therefore confirm the state of stalemate into which interest in opera has fallen in Europe.

Not only the advanced age of the audience and their cultural and socio-economic level, but also logistic problems and the ever-growing lack of free time represent further obstacles to a possible increase in the number of opera-goers.

The most worrying aspect, however, appears to be the very lack of generational exchange that the theatres themselves deem indispensable for their future survival. 
J. Social Sci., 8 (2): 182-188, 2012

Table 1: Fruition of music in Europe through channels other than live performance Year 2003

\begin{tabular}{|c|c|c|c|c|c|c|c|c|c|}
\hline CCEB CC & $\mathrm{C} 13$ & 2004 & & & & Czec & & & \\
\hline 2003,1 aver & verage & meml & bers $\mathrm{Bu}$ & lgaria & Cyprus & Reps & ublic Estoni & ia Hungary & cy Latvia \\
\hline $\begin{array}{l}\text { classical } \\
\text { music }\end{array}$ & 24 & 28 & 17 & & 14 & 33 & 26 & 30 & 31 \\
\hline $\begin{array}{l}\text { opera, } \\
\text { operetta }\end{array}$ & 9 & 14 & 9 & & 3 & 18 & 13 & 26 & 15 \\
\hline $\begin{array}{l}\text { rock, pop } 37 \\
\text { hard rock/ }\end{array}$ & 37 & 44 & 31 & & 25 & 42 & 37 & 34 & 39 \\
\hline $\begin{array}{l}\text { heavy } \\
\text { metal }\end{array}$ & 6 & 10 & 8 & & 5 & 15 & 9 & 8 & 12 \\
\hline $\begin{array}{l}\text { easy } \\
\text { listening }\end{array}$ & 50 & 65 & 63 & & 92 & 62 & 66 & 73 & 74 \\
\hline $\begin{array}{l}\text { dance } \\
\text { /house }\end{array}$ & 18 & 28 & 19 & & 8 & 39 & 42 & 17 & 49 \\
\hline techno & 9 & 15 & 10 & & 4 & 11 & 8 & 12 & 10 \\
\hline Rap & 8 & 12 & 13 & & 6 & 8 & 9 & 12 & 15 \\
\hline $\begin{array}{l}\text { jazz, blues } 11 \\
\text { folk, }\end{array}$ & 11 & 16 & 18 & & 7 & 22 & 13 & 18 & 21 \\
\hline traditional 57 & 57 & 32 & 72 & & 20 & 40 & 29 & 31 & 37 \\
\hline $\begin{array}{l}\text { world } \\
\text { music }\end{array}$ & 19 & 21 & 45 & & 14 & 18 & 27 & 26 & 34 \\
\hline other type 13 & 13 & 9 & 7 & & 2 & 20 & 3 & 10 & 8 \\
\hline Classical & Litu & Iania & Malta & Polanc & d Rom & hania & Slovakia & Slovenia & Turkey \\
\hline music & 28 & & 28 & 25 & 18 & & 38 & 33 & 22 \\
\hline $\begin{array}{l}\text { Opera, } \\
\text { operetta }\end{array}$ & 12 & & 15 & 11 & 9 & & 14 & 11 & 2 \\
\hline Rock, pop & 49 & & 47 & 48 & 21 & & 48 & 43 & 35 \\
\hline $\begin{array}{l}\text { Hard rock/ } \\
\text { Heavy metal }\end{array}$ & 10 & & 5 & 9 & 5 & & 14 & 10 & 2 \\
\hline Easy listening & ng 62 & & 61 & 64 & 63 & & 67 & 65 & 27 \\
\hline Dance/house & e 41 & & 22 & 27 & 24 & & 27 & 22 & 5 \\
\hline Techno & 17 & & 14 & 17 & 10 & & 15 & 13 & 2 \\
\hline Rap & 16 & & 12 & 12 & 9 & & 15 & 15 & 2 \\
\hline Jazz, blues & 19 & & 12 & 13 & 15 & & 20 & 16 & 3 \\
\hline $\begin{array}{l}\text { Folk, } \\
\text { traditional }\end{array}$ & 50 & & 30 & 24 & 71 & & 55 & 56 & 79 \\
\hline World music & c 26 & & 26 & 18 & 31 & & 27 & 18 & 9 \\
\hline other type & 2 & & 7 & 6 & 8 & & 17 & 6 & 20 \\
\hline
\end{tabular}

Source: European Commission, Euro barometer 2003

In fact, stripped of any other combinations of performance, opera-going, at least in over half of the States of the European Union, attracts only $4 \%$ of the population aged between 15 and 24 , against $22 \%$ of those over 55: this leads one to suppose that, without any specifically focused planning, tomorrow's audience will not be able to replace that of today (Elita, 2011).

\section{MATERIALS AND METHODS}

So what exactly are the strategies undertaken by theatres with a view to attracting young people to opera? The answer to this question was the topic of a study I carried out with regards the 2008/2009 season and that I made through the analysis of the web-sites of 24 theatres: 12 of these were members of Reseo, the network of partners involved in opera education that was proposed and promoted by the European Community in 1999 and that currently includes 50 educational departments of the same number of theatres; instead, 12 other theatres, although belonging to other such networks (Fedora, Opera Europa, Centre Francais de Promotion Lyrique, Opera Base,) were not members of Reseo.
Table 2: The 24 theatres examined by the research

\begin{tabular}{ll}
\hline Theatres belonging to Reseo (T1) & Theatres not belonging to Reseo (T2) \\
\hline Opéra National de Paris-Bastille & Opéra Municipal de Marseille \\
Bayrische Staatsoper-München & Deutsche Oper Berlin \\
Oper Frankfurt & Oper Leipzig \\
Teatro Regio-Torino & Wiener Staatsoper \\
Teatro dell'Opera-Roma & Teatro Comunale-Bologna \\
Gran Teatre del Liceu-Barcelona & Teatro Comunale-Firenze \\
Malmö Opera & Teatro Massimo-Palermo \\
English National Opera-London (ENO) & Opéra de Lausanne \\
Royal Opera House-London (ROH) & Stadttheater Bern \\
Théâtre Royal de la Monnaie-Bruxelles & Theater Basel \\
Finnish National Opera-Helsinki & Opera National de Sofiya \\
Den Jyske Opera-Aarhus & Magyar Állami Operahaz-Budapest \\
\hline
\end{tabular}
Source: Elita (2011)

The education of the young audience in 24 european opera-houses: My aim was to highlight the general educational-disseminating strategies adopted by the theatres and, more especially, to pinpoint any commonly shared approaches that might provide an idea of the educational-pedagogic-disseminating direction taken by theatres throughout Europe, over and above any local or national peculiarities.

The theatres examined, shown in Table 2, are representative of 12 different countries: Italy (5), France (3), Germany (3), Switzerland (3), Spain (2), United Kingdom (2), Belgium (1), Finland (1), Austria (1), Sweden (1), Hungary (1) and Bulgaria (1).

They are unhomogeneous not only in their size and capacity, but also in their type of activity, the number of performances given each season and the overall number of productions. They range from the 2716 seats in the Opéra National de Paris to the 750 in the Theater Basel; from the 248 performances at the Wiener Staatsoper, to the 14 at the Opera in Aarhus.

All the theatres provide reductions in the ticket prices for young concert-goers; nearly all offer guided visits around the theatre; all, except one, have an internal educational sector and all the theatres have an educational section on their home page.

The most common educational aim of the theatres is: to help young people and their families to appreciate and understand opera and dance, with a view to creating a new audience for the culture of opera and music. Some theatres set themselves more general aims involving a basic music education more linked to the school curricula than to the theatre's more habitual activity.

\section{RESULTS}

It seemed worthwhile to carry out an analysis of the quantity and type of projects actually offered to the young, to schools and to families. There follows a summary of the results. 


\section{J. Social Sci., 8 (2): 182-188, 2012}

The numerical diversification of the projects: While all the theatres examined try to enact suitable strategies for disseminating opera among the young, it is nevertheless quite evident that the quantity of interventions differs notably between one theatre and another. In the 2008-2009 season Leipzig organised as many as 31 different educational projects; the Royal Opera House in London offered 26, while the compatriate English National Opera arranged 7; the Théâtre Royale de la Monnaie in Brussels activated 22 projects, the Theatre in Basel 21. It can be seen that the number of initiatives offered for young people is not directly related to the size of the theatre. Bern, for example, whose theatre is decidedly small (750 seats), turns out to be more active (14 projects) than the Opéra in Marseille (1837 seats, 4 projects).

The mediators between opera, theatre and the young: The theatres seem to adopt differing strategies to attract young people to opera, sometimes assigning the role of decision-maker to the families, at others to the scholastic institutions. In some cases this choice appears to reflect a national characteristic: Italian theatres have concentrated almost exclusively on schools. The 22 projects offered by the theatre in Brussels are all destined for schools, as are the 2 in Budapest, the 4 in Marseille and the 3 in Lausane, while the Opéra de Paris destines 9 of its 18 projects to both schools and families.

The types of young audience: We found that the theatres address the vast majority of their projects to the age range 6-11 years; this is followed by 11-14, 15-19, infant schools (approx. 3-6), the university and, finally, teacher training courses. There are however certain differences between the theatres: while the Comunale in Bologna by far prefers the 11-18 age range, the theatre in Munich seems to favour younger groups (4-12 years).

The proposals: The projects for young people can be classified into six broad categories that we list here in order of numerical importance: 1. practical workshops (choral singing, dance, music and movement, instrumental practice, dramatizations, animated theatre, interactive games; production of texts, scripts, stagings,).2. Performances and participation in dress rehearsals, concerts and specific recitals, adaptations of operas. 3. Guides to the scheduled performances. 4. Interactive guided visits to the theatres, laboratories, the orchestra, in-house dance schools, theatre museums. 5. Meetings-debates, conferences, lectures. 6. Training courses for teachers.
Generally speaking the schemes tend to favour a practical, hands-on approach to music, opera and theatre, an approach that becomes almost exclusive when the activity is addressed to the children of infant, primary and lower secondary schools. Taking part in performances, dress rehearsals or concerts still holds an important place among the strategies. Of particular significance for their notable immersion in the practical aspect are the projects of the theatre in Leipzig and the English National Opera in London, which also offer courses in choreographic invention, musical games, inventing stories, in make-up and dressing up in costumes, in puppet-sewing, sound exploration, storytelling.

All in all, it can be said that theatres are tending to replace the traditional, more discursive guides to the opera (still addressed to young adults in conference form) with practical and educational workshops. This strategy is adopted at the theatres in Munich, Frankfurt, Rome and Barcelona, at the English National Opera in London, in Brussels, Helsinki, Aarhus, Marseille, Leipzig, Vienna, Florence, Palermo and Bern.

The use of new technology is quite widespread and seems to be imposing itself as a means to replace viva voce: a live performance may often be substituted or integrated by a video projection. The use of new technology sometimes reaches incredible heights: Ópera Oberta, for example, is a project proposed by the Gran teatre Del Liceu in Barcelona that consists of a transmission effected through the internet al lowing the students of the 41 universities involved in the project to watch the six scheduled operas live.

There are also instances of theatres that are particularly sensitive towards the young disabled, offering workshops and representations for the blind or for children affected by autism or Asperg's syndrome (English National Opera in London).

The results of our study highlight certain new trends that are invading the field of production. While certain 'classical' operas for children still seem to be highly successful, a particularly common practice is to make adaptations for children of operas that do not generally appear in the programmes of the theatre. Finally, mention should also be made of the operas by composers and artists who have been commissioned to write works especially for young people (a strategy adopted for example in Paris and Helsinki), this being an indication that the children's market is leading to the opening up of new communicative styles in the art of music.

The didactic methods in the approach to opera: It is possible to identify, at an international level, a school of thought that specifically deals with methods of 


\section{J. Social Sci., 8 (2): 182-188, 2012}

educating young people towards opera. Defined by its advocates as the Scenic interpretation of music theatre, it pivots on the research carried out in the Department of music and theatre at the University of Oldenburg that has for some time also contaminated similar departments of the Universities of Müsterand and of Leeds, becoming the main point of reference for Reseo, the association to which a large part of the Education departments of European theatres belong.

The Scenic interpretation of music theatre refers to a concept of a constructivist type based on action related to experience (Stroh, 2007; Brinkmann et al., 2010). It consists of a method of teaching, mainly addressed to opera-houses, aimed at orienting spendable activities in educational contexts, both scholastic and extra-scholastic, concerning musical theatre, opera and music. Active learning, together with the personal research for solutions guided at a distance by a teacher-tutor, who assumes the role of facilitator of what should result in self-learning, forms the basis of a method that explicitly refers to the constructivist pedagogy and the psychodrama technique proposed by Jacob Levy Moreno.

The Oldenburg approach is characterized by a series of rigorously defined phases. These include a: moment of preparation, during which also the roles are assigned; a phase of Identification in the character of the personages; the Musical dramatization; the Mannerism, which involves the control of the posture, of the movements, of the facial expression, of the gestures, of the listening, of the performing style, but also the control of the sentiments and of the body language in relation to the musical interpretation; the Distancing oneself from the personage and finally the Reflections shared with all those participating.

\section{DISCUSSION}

The participation to opera, especially among young people and at least in over half of the States of the European Union, is much lower than international research has demonstrated by considering only classical music. The European theaters place more energy and financial resources in educational projects for children and youth than what the research has so far proved. The European theaters adopt common educational strategies to attract the young audience.

\section{CONCLUSION}

The lack of generational exchange that the Opera theatres themselves deem indispensable for their future survival has led to consider that tomorrow's audience will not be able to replace that of today.
To cope with increasing costs and decreasing youth audience, the Opera theaters of Europe have adopted common organizational and pedagogical strategies focusing their activities on educational projects involving the young audience through decision makers such as families, communities, associations and especially schools.

\section{ACKNOWLEDGMENT}

The research was conducted for a $\mathrm{PhD}$ thesis discussed at the University of Fribourg $(\mathrm{CH})$ in February 2011: Elita (2011). La diffusione del teatro d'opera nelle giovani generazioni. Strategie delle istituzioni operistiche europee e principi didattici divulgativi. PhD thesis in Musicology and History of Musical Theatre presented to the Faculty of Arts, University of Fribourg (CH). 25th February 2011.

\section{REFERENCES}

Baumol, W.J. and W.G. Bowen, 1981. Performing Arts - the Economic Dilemma: A Study of Problems Common to Theater, Opera, Music and Dance; a Twentieth Century Fund Study. 3rd Edn., MIT Press, Cambridge, ISBN-10: 0262520117, pp: 582.

Bentoglio, A., 2007. L'attività Teatrale e Musicale in Italia: Aspetti Istituzionali, Organizzativi ed Economici. 2nd Edn., Carocci, Roma, ISBN-10: 8843043498, pp: 246.

Bianconi, L., 2005. Parola, azione, musica: Don Alonso Vs Don Bartolo. IL Saggiatore Musicale. Olschki, Firenze.

Brinkmann, R.O., M. Kosuth and W.M. Stroh, 2010. Methoden katalog der zsenische interpretation von musik und theater. Lugert Verlag, Handorf.

Colbert, F., 2000. Marketing Delle Arti e Della Cultura. 3rd Edn., Etas, Milano, ISBN: 8845309797, pp: 318.

Council Conclusions, 1997. Music in Europe (98/C 1/04). Off. J. Eur. Communities., 3: 16-17.

Elita, M., 2011. La diffusione del teatro d'opera nelle giovani generazioni. Postal (Bolzano), Italia.

Eurobarometer, 2003. New europeans and culture. PUBLIC Opinion in the Candidate Countries, European Commission.

Farinha, C., 2007. The Europeans, culture and cultural values - special eurobarometer 278. LabforCulture, European Commission.

Frabboni, F. and L. Guerra, 1991. La Citta Educativa. Verso un Sistema Formativo Integrato. 1st Edn., Cappelli, Bologna, pp: 206. 
Frey, B.S., 2003. Arts and Economics: Analysis and Cultural Policy. 2nd Edn., Springen Verlag, New York, ISBN: 3540002731, pp: 246.

Kiefer, M.L., 2005. Medienokonomik: Einfuhrung in eine Okonomische Theorie der Medien. 2nd Edn., Oldenburg Wissenschaftsverlag, Oldenburg, ISBN: 9783486578218, pp: 485.

Nattiez, J.J., M. Bent, R. Dalmonte and M. Baroni, 2002. Enciclopedia Della Musica. 1st Edn., G. Einaudi, Torino, ISBN: 8806158503, pp: 1156.
Stroh, W.M., 2007. Szenische Interpretation von Musik: Eine Anleitung zur Entwicklung von Spielkonzepten anhand ausgewählter Beispiele. Schöningh Verlag, Braunshweig, ISBN: 9783140180771.

Throsby, D., 1994. The production and consumption of the arts: A view of cultural economics. J. Econ. Literat., 32: 1-29. 